\title{
Infestação por Ctenocephalides felis em bezerros no município de Dores do Indaiá, MG, Brasil
}

Letícia Camêlo Vespasiano;, Layanne Duarte Ferreira, Ronaldo Alves Martins, Matheus Ferreira Serafini, Antônio Último de Carvalho, Rodrigo Melo Meneses, Júlia Angélica Gonçalves da Silveira, Elias Jorge Facury Filho

Departamento de Clínica e Cirurgia Veterinárias, Escola de Veterinária, Universidade Federal de Minas Gerais (UFMG), Belo Horizonte, MG, Brasil

${ }^{*}$ Autor correspondente

e-mail: leticiacvvet@gmail.com

\section{Resumo}

As doenças causadas por parasitas têm se tornado cada dia mais um entrave no desenvolvimento da produção de bovinos no Brasil. Mesmo sendo considerados ectoparasitos espécie-específicos obrigatórios, as pulgas podem espoliar outros hospedeiros na ausência do específico. 0 presente trabalho relata a infestação de bezerros por pulgas Ctenocephalides felis em uma propriedade no município de Dores do Indaiá/MG, em setembro de 2016. Os animais eram mestiços Holandês x Gir, com vários graus de cruzamento, variavam de 0 a 60 dias de idade e eram criados em sistema de bezerreiro tropical coberto por Tifton, com lotação média de 42 animais. Os bezerros recebiam quatro litros de sucedâneo por dia e ração comercial ad libtum. O proprietário relatava uma alta incidência de animais com sinais clínicos de tristeza parasitária. Ao exame físico foi observada maior concentração de pulgas na região da barbela, abdômen e regiões mediais próximas dos membros torácicos e pélvicos, com presença de eritema. Alguns animais também apresentavam áreas de alopecia na face. Exames laboratoriais realizados mensalmente de agosto a outubro mostraram que o volume globular dos animais desta categoria variou de 22 a 46\%, proteína plasmática total de 5,2 a 8,0 g/ dL, e alguns animais apresentavam Babesia bigemina e Anaplasma marginale em esfregaços sanguíneos. Exemplares de pulgas foram coletados, analisados no Laboratório de Protozoologia Veterinária do ICB/ UFMG e classificados como da espécie $C$. felis. Como fator de risco, os cães da propriedade apresentavam alto grau de infestação por pulgas e tinham livre acesso às instalações dos bezerros, podendo se comportar como fonte da infestação. Por realizarem a hematofagia mesmo quando repletas, somente a ação espoliadora e a inflamação cutânea causada pelas pulgas já trazem grandes prejuízos à saúde e ao desempenho animal. 0 potencial de transmissão do A. marginale por $C$. felis deve ser considerado, uma vez que esta é o vetor biológico de outra rickettsia, a Rickettsia felis, mantida nessa pulga por transmissão transovariana e transestadial. A $R$. 
felis é o patógeno causador da febre maculosa em humanos, que é transmitida por pulgas e classificada como uma rickettsiose humana emergente, descrita primeiramente no Texas, em 1991, e atualmente distribuída em vários países de todos os continentes, exceto Antártica, Estados Unidos, México, Brasil, Alemanha, Laos e Taiwan. Com isso, fazem-se necessários mais estudos para elucidar as consequências das pulgas à produtividade dos animais e possíveis doenças que podem ser transmitidas por estes parasitos. 